JURNAL HUKUM REPLIK

Vol 7 No 2, September 2019

P-ISSN: 2337-9251, E-ISSN: 2597-9094

\title{
KEWENANGAN MAHKAMAH AGUNG TERHADAP UJI MATERI PERATURAN KOMISI PEMILIHAN UMUM NOMOR 20 TAHUN 2018 TENTANG LARANGAN CALEG EKS KORUPTOR (Studi Putusan No: 46 P/HUM/2018)
}

\author{
Abdul Syukur Yakub \\ Auliya Khasanofa \\ abdulsyukury@gmail.com \\ auliyakhasanofa@gmail.com
}

Fakultas Hukum Universitas Muhammadiyah Tangerang

\begin{abstract}
ABSTRAK
Kewenangan Mahkamah Agung terhadap uji materi Peraturan Komisi Pemilihan Umum nomor 20 tahun 2018 yang tertuang dalam putusan nomor 48 P/HUM/2018 telah memberi ruang bagi mantan koruptor (pelaku kejahatan luar biasa) untuk menjadi calon anggota legislatif. Penelitian menggunakan jenis penelitian hukum normatif empiris. Penelitian normatif membahas kaidah, doktrin dan asas hukum yang secara luas terdapat dalam ilmu hukum. Penelitian empiris dilakukan penulis sebagai dukungan terhadap pendekatan undang-undang yang umumnya bersifat normatif. Sehingga penelitian tidak menampilkan hukum dalam bentuk yang statis dan kontekstual, melainkan menyajikan fakta sebenarnya dalam penerapan hukum yang faktual. Data primer diperoleh langsung oleh penulis dari tempat yang menjadi objek penelitian. Sedangkan data sekunder diperoleh penulis dari kajian kepustakaan, bahan hukum primer, sekunder dan tersier. Analisis data bersifat deskriptif dengan menerapkan metode kualitatif. Hasil penelitian menunjukan bahwa: Pertama, hakim harus keluar dari kekakuan hukum yang cenderung legisme, serta penafsiran gramatikal tanpa memahami rasa keadilan masyarakat luas. Kedua, harus dilakukan perubahan norma dalam undang-undang nomor 24 tahun 2003 tentang Mahkamah Konstitusi, terutama pasal 55 dan perubahan terhadap undang-undang pemilu yang mengatur pembatasan bagi mantan narapidana kejahatan luar biasa seperti: korupsi, narkotika, kekerasan terhadap anak.

Kata Kunci: Kewenangan, Mahkamah Agung, Uji Materi Calon Legislatif
\end{abstract}


JURNAL HUKUM REPLIK

Vol 7 No 2, September 2019

P-ISSN: 2337-9251, E-ISSN: 2597-9094

\begin{abstract}
The authority of the Supreme Court on the judicial review of the Election Commission Regulation number 20 of 2018 as stipulated in decision number 48 P / HUM / 2018 has given space for former corruptors (extraordinary criminals) to become candidates for legislative members. This research uses empirical normative legal research. Normative research discusses the rules, doctrines and principles of law that are widely contained in the science of law. The author's empirical research as support for the law approach is generally normative in nature. So that research does not display the law in a static and contextual form, but presents the actual facts in the application of factual law. Primary data obtained directly by the writer from the place that is the object of research. Whereas the secondary data were obtained by the writer from the literature study, primary, secondary and tertiary legal materials. Data analysis is descriptive by applying qualitative methods. The results showed that: First, judges must get out of the rigidity of the law that tends to legism, and grammatical interpretation without understanding the sense of justice of the wider community. Second, changes must be made to norms in law number 24 of 2003 concerning the Constitutional Court, especially article 55 and changes to the electoral law which regulates restrictions on ex-convicts of extraordinary crimes such as: corruption, narcotics, violence against children.
\end{abstract}

Keywords: Authority, Supreme Court, Judicial Review of Legislative Candidates.

\title{
I. Pendahuluan
}

Disahkannya Undang-Undang Nomor 7 Tahun 2017 tentang Pemilihan Umum, dan Peraturan Komisi Pemilihan Umum 20 Nomor Tahun 2018 tentang pencalonan anggota Dewan Perwakilan Rakyat Republik Indonesia (DPR RI), Dewan Perwakilan Daerah (DPD), Dewan Perwakilan Rakyat Daerah (DPRD) Provinsi, Dewan Perwakilan Rakyat Daerah (DPRD) Kabupaten/Kota, adalah salah satu contoh yang sangat signifikan menimbulkan selisih pendapat diberbagai kalangan, yang perhatian mengamati jalannya hukum dan perundang-undangan.

Peraturan Komisi Pemilihan Umum (PKPU) Nomor 20 Tahun 2018 pasal 4 ayat 3 yang menyatakan: "Dalam seleksi bakal calon secara demokratis dan terbuka sebagaimana dimaksud pada ayat (2), tidak menyertakan mantan terpidana bandar narkoba, kejahatan seksual terhadap anak, dan korupsi." Norma tersebut melarang mantan terpidana bandar narkoba, kejahatan seksual terhadap anak, dan korupsi mendaftarkan diri sebagai calon anggota legislatif. Padahal, dalam Pasal 28 huruf D Undang-Undang Dasar Negara Republik Indonesia 1945 (UUD NRI Tahun 1945) menyebutkan bahwa "setiap orang 
JURNAL HUKUM REPLIK

Vol 7 No 2, September 2019

P-ISSN: 2337-9251, E-ISSN: 2597-9094

berhak memperoleh kesempatan yang sama dalam pemerintahan". Berdasarkan bunyi pasal tersebut, dalam hal pemilu, hak politik warga negara dalam pemilihan umum termasuk pemilihan kepala daerah, yakni hak untuk memilih dan dipilih merupakan suatu hak asasi yang dijamin dalam UUD NRI Tahun $1945 .{ }^{1}$

Keberadaan tindak pidana korupsi dalam hukum positif Indonesia sebenarnya sudah ada sejak lama, yaitu sejak berlakunya Kitab Undang Undang Hukum Pidana (Wetboek van Strafrecht) 1 Januari 1918. Kitab Undang Undang Hukum Pidana sebagai kodifikasi dan unifikasi berlaku bagi semua golongan di Indonesia sesuai dengan asas konkordansi dan diundangkan dalam Staatblad 1915 nomor 752, tanggal 15 oktober $1915 .^{2}$

Polemik terkait norma dalam peraturan komisi pemilihan umum sebenarnya telah ada sejak peraturan Komisi Pemilihan Umum nomor 20 tahun 2018 disahkan dan ditandatangani. Semakin menjadi perhatian ketika Badan Pengawas Pemilihan Umum (Bawaslu) Republik Indonesia mengeluarkan surat rekomendasi bahwa eks (bekas) koruptor boleh mendaftar menjadi bakal calon anggota legislatif. Sikap bawaslu berpegang pada ketentuan undang-undang nomor 7 tahun 2017 tentang pemilihan umum yang tertuang dalam pasal 240 ayat 1 huruf g UU pemilu yang menyatakan, "Seorang mantan narapidana yang telah menjalani masa hukuman selama lima tahun atau lebih boleh mencalonkan diri selama yang bersangkutan mengumumkan kepada publik." Sementara Komisi Pemilihan Umum RI tetap berpedoman pada peraturan Komisi Pemilihan Umum nomor 20 tahun 2018 yang memuat larangan mantan koruptor manjadi calon wakil rakyat. ${ }^{3}$

Penulisan karya ilmiah ini tidak akan lebih jauh membahas tentang sikap kontradiktif antar sesama penyelenggara pemilihan umum tahun 2019, yakni Komisi Pemilihan Umum Republik Indonesia dan Bawaslu Republik Indonesia dalam menilai layak tidaknya eks koruptor menjadi wakil rakyat. Karena kedua lembaga tersebut memiliki legitimasi yang cukup menurut undang-undang dalam menentukan arah, sikap dan

\footnotetext{
${ }^{1}$ Hanum Hapsari. Dilema Pelarangan Mantan Narapidana Korupsi Mendaftarkan Diri Sebagai Calon Legislatif (https://journal.unnes.ac.id/sju/index.php/snh/article/download/25595/11481/). Diakses pada tanggal 7 April 2019, Pukul 13:10 wib.

${ }^{2}$ Ermansjah Djaja, Memberantas Korupsi Bersama Komisi Pemberantasan Korupsi. (Jakarta: Sinar Grafika), 2008, hlm. 8

${ }^{3}$ https://nasional.kompas.com/read/2018/09/14/21132761/ma-bolehkan-eks-koruptor-jadi-calegbawaslu-minta-tak-ada-lagi-yang-kecewa. Diakses pada tanggal 2 April 2019, Pukul 17:05 Wib.
} 
JURNAL HUKUM REPLIK

Vol 7 No 2, September 2019

P-ISSN: 2337-9251, E-ISSN: 2597-9094

kebijakan menjalankan amanah, tugas, dan fungsinya untuk mensukseskan jalannya penyelenggaraan pemilihan umum tahun 2019 secara demokratis, yang sejatinya berlangsung umum, bebas, rahasia, jujur dan adil.

Berdasarkan uraian masalah tersebut, penulis memberi judul penulisan karya ilmiah ini: "Kewenangan Mahkamah Agung Terhadap Uji Materi Peraturan Komisi Pemilihan Umum Nomor 20 Tahun 2018 Tentang Larangan Caleg Eks Koruptor.” (Studi Putusan Nomor: 46 P/HUM/2018).

Berdasarkan latar belakang dan identifikasi masalah yang telah diuraikan sebelumnya, maka Bagaimana pertimbangan hukum Mahkamah Agung dalam mengeluarkan putusan uji materi Peraturan Komisi Pemilihan Umum Nomor 20 Tahun 2018 tentang larangan caleg eks koruptor terhadap UU Nomor 7 Tahun 2017 Tentang Pemilu dan Bagaimana implikasi putusan Mahkamah Agung terhadap penyelenggaraan Pemilihan Umum Tahun 2019 yang dilaksanakan secara serentak Nasional, khususnya pemilihan Calon Anggota Legislatif yang berasal dari Partai Politik peserta pemilu.

Adapun yang menjadi tujuan dalam penelitian ini untuk mengkaji sejauh mana mahkamah agung menyusun suatu pertimbangan hukum yang benar dan tepat dan untuk mengetahui sifat final dan mengikat putusan mahkamah agung terhadap jalannya penyelenggaraan pemilihan umum tahun 2019, terutama dalam hal pendaftaran, verifikasi dan penetapan Calon Anggota Legislatif.

\section{Metode Penelitian}

Penelitian ini merupakan jenis penelitian hukum normatif empiris atau socio-legal research, yang pada dasarnya merupakan penggabungan antara pendekatan hukum normatif meliputi pendekatan konseptual, pendekatan undang-undang, pendekatan kasus, pendekatan perbandingan, yang bersifat deskriptif analisis. Dipadukan dengan berbagai unsur empiris, meliputi pendekatan sosial. Metode penelitian normatif-empiris mengenai implementasi ketentuan hukum normatif (undang-undang) dalam aksinya pada setiap peristiwa hukum tertentu yang terjadi dalam suatu masyarakat.

Metode penelitian hukum empiris dapat dikatakan sebagai penelitian hukum sosiologis. Penelitian hukum sosiologis atau empiris adalah metode 
JURNAL HUKUM REPLIK

Vol 7 No 2, September 2019

P-ISSN: 2337-9251, E-ISSN: 2597-9094

penelitian yang dilakukan untuk mendapatkan data primer dan menemukan kebenaran dengan menggunakan metode berfikir induktif dan kriterium kebenaran koresponden serta fakta yang digunakan untuk melakukan proses induksi dan pengujian kebenaran secara koresponden adalah fakta yang mutakhir.

Sumber Data dalam melakukan penelitian karya tulis ilmiah ini, menggunakan beberapa Data Primer, yaitu data yang diperoleh atau didapat langsung peneliti tanpa perantara pihak lain dari objek/tempat penelitian, yang merupakan bahan-bahan hukum positif, seperti: Salinan Putusan Mahkamah Agung Nomor 46 P/HUM/2018 dan data sekunder, yaitu data yang diperoleh peneliti secara tidak langsung dari sumbernya, tetapi dari sumber lain. Peneliti mendapatkan data yang sudah jadi yang dikumpulkan baik komersil maupun non komersil, seperti didapat dari buku-buku, jurnal (studi kepustakaan), literatur-literatur dan pendapat-pendapat hukum yang berasal dari antara lain:

1. Bahan Hukum Primer Yaitu Bahan-bahan hukum yang mempunyai kekuatan hukum mengikat secara yuridis, yang terdiri dari: Pertama, Norma Dasar (Pancasila), Kedua, Peraturan Dasar: Batang Tubuh UUD NRI 1945, TAP MPR. Ketiga, Peraturan perundang-undangan. Keempat, Hukum yang tidak dikodifikasi: hukum adat, hukum islam. Kelima, Yurisprudensi. Keenam, Traktat.

2. Bahan Hukum Sekunder Yaitu bahan hukum yang erat kaitannya dengan penelitian yakni bahan hukum primer. Untuk membantu menganalisis dan memahami bahan hukum primer, dapat berupa: Rancangan peraturan perundang-undangan, perundang-undangan yang tidak berlaku, hasil karya ilmiah para sarjana, hasil-hasil penelitian, jurnal dan lain sebagainya.

3. Bahan Hukum Tersier Berupa komplementer untuk bahan hukum sekunder dan tersier contohnya adalah Kamus Hukum.

\section{Hasil Penelitian dan Analisa}

\section{Hasil Penelitian Pada Mahkamah Agung Dan Komisi Pemilihan Umum Republik Indonesia}




\section{a. Jadwal Penelitian}

\begin{tabular}{|c|l|l|}
\hline \multicolumn{1}{|c|}{ Plan } & \multicolumn{1}{|c|}{$\begin{array}{c}\text { Instansi/Lembaga } \\
\text { /Narasumber }\end{array}$} & \multicolumn{1}{|c|}{ Actual } \\
\hline Nov 2018 - Juli 2019 & Mahkamah Agung & $\begin{array}{l}\text { 19 Des 2018 \& } \\
\text { 25 Juli 2019 }\end{array}$ \\
\hline Mei 2019 - Juli 2019 & $\begin{array}{l}\text { Komisi Pemilihan } \\
\text { Umum }\end{array}$ & 17 Juli 2019 \\
\hline Juni 2019 - Juli 2019 & $\begin{array}{l}\text { Ahli Hukum Tata } \\
\text { Negara }\end{array}$ & 30 Juli 2019 \\
\hline
\end{tabular}

\section{b. Tempat dan Waktu Penelitian}

Penelitian dilakukan sejalan dengan permasalahan yang diangkat dalam penyusunan karya tulis ini yang berjudul "Kewenangan Mahkamah Agung Terhadap Uji Materi Peraturan Komisi Pemilihan Umum Nomor 20 Tahun 2018 Tentang Larangan Caleg Eks Koruptor". Sehingga penelitian dilakukan dilingkungan Mahkamah Agung Republik Indonesia dan Komisi Pemilihan Umum. Sedangkan untuk waktu yang pelaksanakan adalah sejak november 2018 hingga juli 2019.

Yang menjadi pertimbangan untuk melakukan penelitian dilingkungan Mahkamah Agung Republik Indonesia, dan Komisi Pemilihan Umum tentunya linear dengan judul diatas dan cukup substansial dengan objek penelitian. Adapun pemilihan waktu yang cukup, agar mendapatkan gambaran sepenuhnya tentang objek penelitian. Menarik pula bahwa dalam tahapan penelitian, mengalami kendala waktu penelitian yang dikarenakan salah satu instansi/lembaga dalam hal ini Komisi Pemilihan Umum sedang bergelut dengan tahapan penyelenggaraan pemilihan umum tahun 2019.

2. Analisis Pertimbangan Mahkamah Agung Dalam Putusan Uji Materi Peraturan Komisi Pemilihan Umum Nomor 20 Tahun 2018

Hampir 2 (dua) dekade pasca reformasi dan disahkannya undang undang nomor 28 tahun 1999 tentang penyelenggaraan negara yang bersih dari korupsi, kolusi dan nepotisme. Kehidupan 
JURNAL HUKUM REPLIK

Vol 7 No 2, September 2019

P-ISSN: 2337-9251, E-ISSN: 2597-9094

berbangsa dan bernegara masyarakat indonesia masih diliputi oleh permasalahan korupsi yang tak kunjung usai. Bahkan kecenderungannya semakin meningkat, sekalipun telah lahir dan berjalannya suatu lembaga anti rasuah yakni Komisi Pemberantasan Korupsi (KPK).

Tindak pidana korupsi merupakan masalah yang sangat serius, karena tindak pidana korupsi dapat membahayakan stabilitas nasional dan keamanan negara dan masyarakat, membahayakan pembangunan sosial dan ekonomi masyarakat, politik, bahkan pula merusak nilai-nilai demokrasi serta moralitas bangsa karena dapat berdampak membudayanya tindak pidana korupsi tersebut. ${ }^{4}$ Lord Acton pernah membuat sebuah ungkapan yang menghubungkan antara korupsi dengan kekuasaan, yakni "power tends to corrupt, and absolute power corrupts absolutely".5

Hal ini yang mendasari komisi Pemilihan Umum membuat norma baru dalam peraturannya yang melarang mantan napi koruptor, kejahatan seksual terhadap anak, dan narkotika, mendaftar menjadi calon anggota legislatif. Hal ini disampaikan oleh help desk teknis penyelenggaraan pemilihan umum tahun 2019, yakni Bapak Razi Sabardi. Komisi Pemilihan Umum mengatur norma tersebut bukan tanpa dasar, melainkan telah melalui proses panjang seperti: melaksanakan prosedur penyusunan, perumusan dan penetapan sebuah peraturan perundang-undangan yang baik dan benar, mengundang para ahli hukum, Badan Pengawas Pemilu (Bawaslu RI, Lembaga Swadaya Masyarakat (LSM), Wartawan/Jurnalis, rapat dengar pendapat (RDP) dengan Komisi II DPR RI, menyurati Komisi Pemberantasan Korupsi (KPK), dan menyurati Presiden Republik Indonesia melalui Sekretariat Negara.

Menurut Ahmad Redi, ahli hukum tata negara Fakultas Hukum Universitas Tarumanagara, pertimbangan hukum oleh majelis hakim dalam putusan Mahkamah Agung Nomor 46P/HUM/2018 yang menyatakan bahwa peraturan Komisi Pemilihan Umum Nomor 20 tahun 2018 bertentangan dengan undang-undang nomor

\footnotetext{
${ }^{4}$ Ermansjah Djaja. Op. Cit. hlm. 2
}

${ }^{5}$ Ibid, hlm. 1 
JURNAL HUKUM REPLIK

Vol 7 No 2, September 2019

P-ISSN: 2337-9251, E-ISSN: 2597-9094

7 tahun 2017 tentang pemilihan umum, sudah tepat namun cenderung legisme.

Montesquieu yang seorang hakim mengimpikan pemisahan kekuasaan yang ekstrem antara cabang-cabang kekuasaan legislatif, ekskutif dan terutama kekuasaan yudisial. ${ }^{6}$ Pemisahan kekuasaan juga terkait dengan independensi peradilan. Prinsip pemisahan kekuasaan (separation of power) itu menghendaki bahwa para hakim dapat bekerja secara independen dari pengaruh kekuasaan eksekutif dan legislatif. Bahkan dalam memahami dan menafsirkan undang-undang dasar dan undang-undang, hakim harus independen dari pendapat dan bahkan dari kehendak politik perumus undang-undang dasar dan undang-undang itu sendiri ketika perumusan dilakukan. ${ }^{7}$

Bagi masyarakat indonesia telah melekat bahwa hakim merupakan sebuah jabatan yang sangat mulia dan hakim adalah wakil tuhan dimuka bumi, sehingga putusan hakim diartikan sebuah keputusan yang mulia dan tentunya telah memenuhi seluruh unsur keadilan yang dibutuhkan masyarakat pencari keadilan. Hal ini yang sejati hadir dalam setiap putusan majelis hakim diberbagai pegadilan negara Indonesia, sesuai dengan amanat konstitusi yakni Pancasila dan UUD NRI Tahun 1945.

Pasal 5 ayat 1 undang undang nomor 48 tahun 2009 tentang kekuasaan kehakiman menyatakan: "Hakim dan hakim konstitusi wajib menggali, mengikuti, dan memahami nilai-nilai hukum dan rasa keadilan yang hidup dalam masyarakat". Kemudian penjelasan masih dalam pasal dan ayat yang sama menyatakan: "Ketentuan ini dimaksudkan agar putusan hakim dan hakim konstitusi sesuai dengan hukum dan rasa keadilan masyarakat". Secara sederhana dapat ditafsirkan bahwa hakim dalam membuat pertimbangan hukum dalam putusan tersebut tidak memahami rasa keadilan yang hidup dalam masyarakat secara luas.

Rasa keadilan terkadang hidup diluar undang-undang, yang jelas undang-undang akan sulit mengimbanginya. Begitu pula sebaliknya undang-undang dirasakan tidak adil. Ketika rasa keadilan ini benar-benar eksis dan dirasakan oleh mayoritas kolektif, maka kepastian hukum akan bergerak menuju rasa keadilan itu sendiri. Kepastian hukum adalah rasa keadilan itu

${ }^{6}$ Jimly Asshiddiqie, Op. Cit. hlm. 310

${ }^{7}$ Ibid. hlm. 311 
JURNAL HUKUM REPLIK

Vol 7 No 2, September 2019

P-ISSN: 2337-9251, E-ISSN: 2597-9094

sendiri dan sebab keadilan dan hukum bukanlah dua elemen yang terpisahkan. ${ }^{8}$

Rasa keadilan memiliki kaitan yang erat dengan hukum dan nilai-nilai sosial budaya masyarakat itu ternyata bahwa hukum yang baik tidak lain adalah hukum yang mencerminkan nilai-nilai yang hidup dalam masyarakat. Indonesia masa kini berada dalam masa transisi, yaitu sedang terjadi perubahan nilai-nilai dalam masyarakat dari nilai-nilai yang bersifat tradisional ke nilai-nilai yang bersifat modern. ${ }^{9}$

Berdasarkan regulasi mungkin sudah tepat bahwa Mahkamah Agung berwenang untuk memeriksa, mengadili dan memutus perkara pengujian peraturan perundang-undangan terhadap undang-undang. Namun, sejatinya Mahkamah juga harus melihat kembali bahwa peraturan yang dibuat oleh Komisi Pemilihan Umum adalah sebuah terobosan hukum dalam menciptakan suasana kehidupan berbangsa dan bernegara yang bertujuan untuk mencapai penyelenggaraan negara yang bersih dari korupsi.

Sekalipun Mahkamah berpandangan bahwa peraturan tersebut dibuat dan disusun serta disahkan dalam komposisi yang tidak memenuhi asas hukum Lex Superior Derogat Legi Inferior, artinya hukum yang diatas (UU Nomor 7 tahun 2017) lebih diutamakan dari hukum dibawahnya (PKPU nomor 20 tahun 2018).

Menjadi anomali ketika dalam salah satu pertimbangannya, secara implisit mahkamah berpendapat bahwa bila peraturan dianggap tidak bertentangan dengan undang-undang pemilu, maka mahkamah telah membiarkan terjadinya pelanggaran Hak Asasi Manusia (HAM). Bukankah sebaliknya, bahwa dengan membiarkan napi mantan korupsi menjadi calon anggota legislatif telah membuka setidaknya beberapa peluang negatif sebagai berikut:

a. Yang bersangkutan masuk dalam DCT Caleg sekalipun tidak terpilih karena jumlah suara yang diperoleh tidak memenuhi jumlah suara minimum. Maka hak suara yang seharusnya

\footnotetext{
${ }^{8}$ Sukarno Aburaera et al. Filsafat Hukum Teori dan Praktik. (Jakarta: Kencana Prenada Media Group, 2014). hlm. 179

${ }^{9}$ Lili Rasjidi dan Liza Sonia Rasjidi, Dasar Dasar Filsafat dan Teori Hukum. (Jakarta: Citra Aditya Bakti, 2012). hlm. 80
} 
JURNAL HUKUM REPLIK

Vol 7 No 2, September 2019

P-ISSN: 2337-9251, E-ISSN: 2597-9094

menjadi hak suara calon legislatif yang bukan mantar koruptor menjadi berkurang bahkan hilang;

b. Caleg eks koruptor terpilih, maka akan mengulangi perbuatannya. Karena kejahatan korupsi dan kejahatan lainnya dapat terjadi karena selain ada niat dari pelaku juga karena ada/diberikannya kesempatan;

c. Bila eks koruptor sah menjadi anggota legislatif dan mengulangi perbuatannya, maka semakin banyak kerugian yang dialami negara, dan semakin banyak hak warga negara yang hilang oleh karenanya.

d. Menutup peluang sebesar-besarnya bagi orang-orang baik untuk mengabdi kepada negara dengan menjadi anggota legislatif, utamanya bagi mereka yang tidak begitu dikenal masyarakat. Sebuah keuntungan bagi calon anggota legislatif kendatipun mereka eks koruptor, karena setidaknya mereka telah terlebih dahulu dikenal oleh publik.

Uraian diatas menunjukan pelanggaran hak asasi manusia justru cenderung lebih besar dan lebih kuat dilakukan oleh para mantan napi korupsi. Hal ini menjadi riskan dan memprihatinkan, ditengah iklim demokrasi untuk membangun negeri. Bangsa ini masih berdebat tentang hak asasi manusia yang secara utuh dan penuh telah diatur oleh the founding fathers melalui konstitusi.

3. Progresivitas Hakim Dalam Putusan Mahkamah Agung Terhadap Uji Materi Peraturan Komisi Pemilihan Umum Nomor 20 Tahun 2018

Pemikiran hukum progresif dalam hubungan dengan perwujudan keadilan, pernah pula dikemukakan oleh salah seorang hakim Agung, Bismar Siregar, dengan menyatakan: "Bila untuk menegakkan keadilan saya harus korbankan kepastian hukum, akan saya korbankan hukum itu. Hukum hanya sarana sedang tujuannya adalah keadilan, mengapa tujuan dikorbankan karena 
JURNAL HUKUM REPLIK

Vol 7 No 2, September 2019

P-ISSN: 2337-9251, E-ISSN: 2597-9094

sarana". Dengan begitu, dalam menerapkan hukum progresif untuk mewujudkan keadilan substantif, hakim harus berani untuk mengesampingkan substansi hukum yang dinilai buruk dan menghambat pencapaian keadilan sosial masyarakat. ${ }^{10}$

Terdapat hal menarik dalam penerapan hukum oleh majelis hakim Mahkamah Agung terkait putusan nomor 46P/HUM/2018, yakni adanya surat menyurat antara Mahkamah Agung dengan Mahkamah Konstitusi Republik Indonesia terkait substansi uji materi yang secara substansial tidak diatur oleh undang-undang namun terdapat celah hukum untuk menjadi sebuah jalan keluar atau penemuan hukum.

Surat pemberitahuan Nomor: 24/HK.06/9/2018 dari Mahkamah Konstitusi kepada Mahkamah Agung, tertanggal 12 September 2018, perihal permintaan data. Menjawab permasalahan dengan adanya inisiatif oleh Mahkamah Agung terkait pasal-pasal yang diuji materikan di Mahkamah Agung tidaklah sama dengan yang diuji materikan di Mahkamah Konstitusi. Menjadi sebuah terobosan atau penemuan hukum oleh majelis hakim, hanya saja hal tersebut tidak tepat.

Bagaimana tidak, dengan berpedoman kepada surat tersebut majelis hakim dapat melanjutkan proses memeriksa, mengadili dan memutus perkara a quo. Yang sejatinya perkara tersebut tetap dilakukan penundaan sementara, sampai adanya putusan Mahkamah Konstitusi terkait uji materi undang-undang nomor 7 tahun 2017 tentang pemilu terhadap UUD NRI 1945 tentang presidential threshold. Putusan Mahkamah Konstitusi nomor: 93/PUU-XV/2017 tegas menyatakan "Pengujian peraturan perundang-undangan di bawah undang-undang yang sedang dilakukan Mahkamah Agung ditunda pemeriksaannya apabila undang-undang yang menjadi dasar pengujian peraturan tersebut sedang dalam proses pengujian Mahkamah Konstitusi sampai ada putusan Mahkamah Konstitusi”.

Sehingga tepat apabila progresivitas dalam perkara a quo ditempatkan dalam peraturan Komisi Pemilihan Umum yang melarang mantan napi koruptor mencalonkan diri menjadi calon anggota legislatif, sekalipun ketentuan dalam perturan tersebut masih dipandang tidak memenuhi tata cara pembentukan peraturan perundang-undangan yang baik sebagaimana diatur dalam undang-undang nomor 12 tahun 2011. Dan

10 http://jurnalnasional.ump.ac.id/index.php/KOSMIK/article/view/2338/1813. Diakses pada tanggal 11 Agustus 2019, pukul 13:34 Wib. 
JURNAL HUKUM REPLIK

Vol 7 No 2, September 2019

P-ISSN: 2337-9251, E-ISSN: 2597-9094

bukan sebaliknya, dengan menempatkan dalam putusan mahkamah agung yang bersifat inisiatif, terobosan atau penemuan hukum oleh majelis hakim. Menilai dan mengesampingkan hukum acara yang bersinggungan dengan undang-undang atau peraturan perundang-undangan lainnya, dalam hal ini undang-undang Mahkamah Konsitusi nomor 24 tahun 2003, termasuk putusan Mahkamah Konstitusi nomor: 93/PUU-XV/2017.

Yang dilakukan oleh Komisi Pemilihan Umum dalam peraturannya merupakan bagian dari hak atribusi suatu lembaga yang diberikan langsung oleh undang-undang. Sekaligus menampilkannya menjadi sebuah terobosan hukum atau hukum yang bersifat progresif yang sejalan dengan tujuan negara dan semangat reformasi yang tertuang dalam undang-undang nomor 28 tahun 1999 tentang penyelenggaraan negara yang bebas dari korupsi, kolusi dan nepotisme.

\section{Implikasi putusan Mahkamah Agung terhadap penyelenggaraan Pemilihan Umum Tahun 2019 yang dilaksanakan secara serentak Nasional.}

Disahkannya peraturan Komisi Pemilihan Umum nomor 20 tahun 2018 sejak juli 2018 memberikan dampak yang sangat positif terhadap penurunan jumlah calon anggota legislatif terindikasi mantan koruptor. Ditambah dengan adanya penandatangan fakta integritas oleh partai politik peserta pemlihan umum tahun 2019, termasuk dari calon perseorangan Dewan Perwakilan daerah (DPD).

Meskipun demikian peraturan tersebut tidak menihilkan calon anggota legislatif terindikasi eks koruptor yang mendaftar. Dapat dimaklumi Komisi Pemilihan Umum menerima karena masih dalam kapasitas atau tahapan pendaftaran calon sementara yang termuat dalam DCS (Daftar Calon Sementara) sesuai peraturan KPU Nomor 9 Tahun 2019 tentang Tahapan, Program dan Jadwal Penyelenggaraan Pemilihan Umum Tahun 2019.

Menjadi lain cerita, ketika uji materi peraturan komisi pemilihan umum nomor 20 tahun 2018 terkait frasa yang menyatakan larangan caleg eks koruptor dibatalkan oleh Mahkamah Agung pada 13 september 2018. Memberikan perubahan yang sangat signifikan terhadap kenaikan jumlah pendaftaran calon anggota legislatif terindikasi mantan napi korupsi sebagimana terlampir dalam tabel 3.3 dan tabel 3.4. 
JURNAL HUKUM REPLIK

Vol 7 No 2, September 2019

P-ISSN: 2337-9251, E-ISSN: 2597-9094

Masyarakat yang terdaftar menjadi pemilih pemilihan umum tahun 2019 baik dalam DPT (Daftar Pemilih Tetap), DPK (Daftar Pemilih Khusus), maupun DPTB (Daftar Pemilih Pindahan) semakin bingung dan tidak lagi fokus daalm menggunakan hak pilihnya, khususnya untuk membedakan calon anggota legislatif pilihannya yang tidak terindikasi mantan napi korupsi. Oleh karena jumlah kertas surat suara yang diterima sangat banyak yakni 5 (lima) jenis kertas surat suara, banyaknya Calon Legislatif terdaftar baik Dewan Perwakilan Daerah, Dewan Perwakilan Rakyat RI, Dewan Perwailan Rakyat Daerah Provinsi, Dewan Perwakilan Rakyat Daerah Kabupaten/Kota.

Putusan tersebut berimplikasi kepada sikap masyarakat yang tidak lagi mempedulikan terhadap caleg pilihannya, apakah mantan koruptor atau bukan. Sehingga semakin kecil harapan masyarakat/pemilih dalam pemilihan umum tahun 2019 untuk mendapatkan para wakil rakyat yang bersih dari korupsi, kolusi dan juga nepotisme, sesuai amanat reformasi yang digaungkan sejak 2 (dua) dekade.

Selain itu, membuat kita sebagai warga negara Indonesia terjebak paradigma (kerangka berfikir) positivistik dalam mengartikan hukum dan mengiplementasikannya dikehidupan bermasyarakat, berbangsa dan bernegara. Padahal sejak amandemen ketiga UUD NRI tahun 1945, negara Indonesia adalah Negara Hukum. Bukan recht staat ataupun rule of law, melainkan negara hukum prismatik atau negara hukum pancasila. Hal tersebut secara eksplisit mewajibkan hukum ditegakkan secara proporsionalitas dalam melihat kasus perkasus, tidak terjebak dalam paradigma legalistik atau terbatas sempit hanya tertuju kepada apa yang tertuang dalam undang-undang. Melainkan hukum terus hidup mengikuti perkembangan zaman dalam kehidupan warga negara. Sehingga penegakkan hukum dapat bersifat legalistik juga progresif, mengikuti permasalahan yang dihadapinya.

Progresivisme hukum menjadi indah dan mengindahkan kehidupan warga negara bila dijalankan sesuai dengan nilai-nilai yang lahir, tumbuh, berkembang dan hidup dalam masyarakat. Nilai yuridis penegakkan hukum seiring sejalan dengan nilai filosofis dan sosiologis warga negara, sebagaimana sejarah pendirian Negara Kesatuan Republik Indonesia. Terciptalah apa yang dicita-citakan Profesor Satjipto rahardjo bahwa 'hukum untuk masyarakat, bukan masyarakat untuk hukum'. 
JURNAL HUKUM REPLIK

Vol 7 No 2, September 2019

P-ISSN: 2337-9251, E-ISSN: 2597-9094

\section{Penutup}

\section{Kesimpulan}

Setelah melakukan anilisis dan pembahasan pada bab sebelumnya dalam penelitian ini, penulis merumuskan kesimpulan sebagai berikut:

a. Pertimbangan hukum oleh hakim dalam menetapkan suatu putusan wajib memahami rasa keadilan yang hidup dalam masyarakat secara luas. Rasa keadilan terkadang hidup diluar undangundang, dan rasa keadilan bergerak menuju keadilan yang hakiki. Karena keadilan dan hukum merupakan satu kesatuan yang tak terpisahkan. Hakim adalah wakil tuhan dimuka bumi, sehingga putusan hakim diartikan sebuah keputusan yang mulia dan tentunya telah memenuhi seluruh unsur keadilan yang dibutuhkan masyarakat pencari keadilan. Hal ini yang sejatinya hadir dalam setiap putusan majelis hakim diberbagai pengadilan negara Indonesia.

b. Putusan Mahkamah Agung dalam uji materi peraturan Komisi Pemilihan Umum berimplikasi langsung terhadap jalannya penyelenggaraan pemilihan umum tahun 2019. Terutama dalam hal peningkatan jumlah calon anggota legislatif yang terindikasi sebagai mantan napi koruptor. Hal ini menimbulkan sikap apriori pada masyarakat dalam menentukan pilihannya memilih wakil rakyat yang akan duduk dalam kursi parlemen. Pemilu sebagai ajang evaluasi menilai kinerja anggota legislatif perlima tahun tidak tercapai, oleh karena mantan koruptor masih mendapat ruang yang tak terkendali untuk mengulangi perbuatannya.

\section{Saran}

Di akhir penulisan ini penulis memberikan saran dalam menghadapi masalah pembangunan hukum di Indonesia, antara lain:

a. Hakim wajib berpegang teguh pada konstitusi yakni Pancasila dan UUD NRI 1945 secara utuh. Mampu keluar dari kekakuan hukum, yang cenderung legisme dan pragmatik, serta menafsirkan sebatas gramatikal tanpa memahami rasa keadilan yang hidup dalam masyarakat luas. 
JURNAL HUKUM REPLIK

Vol 7 No 2, September 2019

P-ISSN: 2337-9251, E-ISSN: 2597-9094

b. Harus dilakukan perubahan norma dalam undang-undang nomor 24 tahun 2003 tentang Mahkamah Konstitusi, terutama pasal 55 dan undang-undang kepemiluan sebaiknya mengatur pembatasan hak dipilih warga negara dalam penyelenggaraan pemilihan umum. Sebagai tafsir menghormati hak asasi orang lain, dan bahwa setiap orang wajib tunduk terhadap pembatasan hak yang ditetapkan undang-undang.

\section{Daftar Pustaka}

Aburaera, Sukarno, Muhadar dan Maskun. Filsafat Hukum Teori dan Praktik. Jakarta: Kencana Prenada Media Group. 2014.

Asshiddiqie, Jimly. Pengantar Ilmu Hukum Tata Negara. Jakarta: Raja Grafindo Persada. 2016.

Asshiddiqie, Jimly. Hukum Acara Pengujian Undang Undang. Jakarta: Sinar Grafika. 2012.

Budiardjo, Miriam. Dasar Dasar Ilmu Politik. Jakarta: Gramedia Pustaka Utama. 2008.

Djaja, Ermansjah. Memberantas Korupsi Bersama KPK. Jakarta: Sinar Grafika. 2008.

Harahap, M. Yahya. Hukum Acara Perdata Tentang Gugatan, Persidangan, Penyitaan, Pembuktian, dan Putusan Pengadilan. Jakarta: Sinar Grafika. 2015.

Harahap, M. Yahya. Kekuasaan Mahkamah Agung Pemeriksaan kasasi dan Peninjauan Kembali Perkara Perdata. Jakarta: Sinar Grafika. 2006.

HR, Ridwan. Hukum Administrasi Negara. Jakarta: Raja Grafindo Persada. Jakarta: 2017.

MD, Mahfud. Politik Hukum di Indonesia. Jakarta: Rajawali Pers. 2014.

Rahardjo, Satjipto. Penegakkan Hukum Progresif. Jakarta: Kompas Media Nusantara. 2010.

Rasjidi, Lili dan Liza Sonia Rasjidi, Dasar Dasar Filsafat dan Teori Hukum. Jakarta: Citra Aditya Bakti. 2012.

Siahaaan, Maruarar. Hukum Acara Mahkamah Konstitusi Republik Indonesia. Jakarta: 2012.

Soeprapto, Maria Farida Indrati. Ilmu Perundang-undangan; Dasar-Dasar dan Pembentukannya. Jakarta: Kanisius. 1998.

Suteki, Masa Depan Hukum Progresif. Yogyakarta: Thafa Media. 2015. 
JURNAL HUKUM REPLIK

Vol 7 No 2, September 2019

P-ISSN: 2337-9251, E-ISSN: 2597-9094

Suteki, dan Galang Taufani. Metodologi Penelitian Hukum (Filsafat, Teori dan Praktik). Jakarta: Raja Grafindo Persada. 2018.

Hanum Hapsari. Dilema Pelarangan Mantan Narapidana Korupsi Mendaftarkan Diri Sebagai Calon Legislatif (https://journal.unnes.ac.id/sju/index.php/snh/article/download/25595/1148 $1 /)$.

Saldi Isra. Titik Singgung Wewenang Mahkamah Agung Dengan Mahkamah Konstitusi. (https://www.saldiisra.web.id/index.php/21makalah/makalah1/635-titik-singgung-wewenang-mahkamah-agungdengan-mahkamah-konstitusi.html).

Ratnia Solihah Siti Witianti Pelaksanaan Fungsi Legislasi Dewan Perwakilan Rakyat Pasca Pemilu 2014: Permasalahan Dan Upaya Mengatasinya. (jurnal.unpad.ac.id/cosmogov/article/download/10010/pdf).

Reza Rahmat Yamani. http://repositori.uinalauddin.ac.id/3263/1/SKRIPSI\%20REZA\%20RAHMAT\%20YAMANI.P $\underline{\mathrm{DF}}$

Undang Undang Dasar Negara Republik Indonesia Tahun 1945

Undang Undang Nomor Tahun 48 Tahun 2009 Tentang Kekuasaaan Kehakiman

Undang Undang Nomor 12 Tahun 2011 Tentang Pembentukan Peraturan Perundang Undangan

Undang Undang Nomor 28 Tahun 1999 Tentang Penyelenggaraan Negara Yang Bersih Dan Bebas Dari Korupsi, Kolusi, Dan Nepotisme

Undang Undang Nomor 7 Tahun 2017 Tentang Pemilihan Umum Undang Undang Nomor 5 Tahun 2004 Tentang Mahkamah Agung Undang Undang Nomor 24 Tahun 2003 Tentang Mahkamah Konstitusi Undang Undang Nomor 12 Tahun 1995 Tentang Pemasyarakatan (https://www.kompasiana.com/abdu_umar/5b2d15155e137307dd4cbe12/uji-materipresidential-threshold-denny-indrayana-dan-kepentingan-politik-dibelakangnya).

(https://www.cnnindonesia.com/nasional/20180906183356-32-328300/polemikeks-koruptor-nyaleg-ma-tak-perlu-tunggu-putusan-mk).

(https://www.hukumonline.com/berita/baca/lt589a813053fd0/setelah-putusan-no-buruh-tetap-berniat-ajukan-uji-materi-pp-pengupahan).

https://www.hukumonline.com/klinik/detail/cl4257/judicial-review-vs-hak-ujimateriil.

http://www.negarahukum.com/hukum/pengertian-kewenangan.html. https://www.mahkamahagung.go.id/id/tugas-pokok-dan-fungsi 
JURNAL HUKUM REPLIK

Vol 7 No 2, September 2019

P-ISSN: 2337-9251, E-ISSN: 2597-9094

https://www.hukumonline.com/klinik/detail/ulasan/lt58dca7c78ab7d/arti-asas-iiuscuria-novit-i.

http://jurnalnasional.ump.ac.id/index.php/KOSMIK/article/view/2338/1813

http://dedyahmadkurniady.staf.upi.edu/2015/08/14/bahan-mata-kuliah-kekuasaandan-kewenangan/ 